\title{
Vezetői és beszállítói vélemények a mezőgazdaság és a turizmus összekapcsolódásának lehetőségeiről Zala megyében
} BRLJAK Zoran ${ }^{1}$, KŐMÜVES Zsolt2², VIG Salma Stella ${ }^{1}$

${ }^{1}$ Educons Egyetem, Sremska Kamenica Gazdaságtudományi Kar, 21208 Novi Sad Војводе П. бб ${ }^{2}$ Szent István Egyetem Kaposvári Campus, 7400 Kaposvár, Guba S. u. 40.

\author{
ABSTRACT - Leader's opinion about the connecting points Agriculture and Tourism within ca- \\ tering trade \\ Author: Zoran Brljak ${ }^{1}$, Zsolt Kőmüves ${ }^{2}$, Salma Stella Vig ${ }^{1}$ \\ Affiliation: ${ }^{1}$ Educons University, Војводе Путника бб, 21208 Novi Sad; ${ }^{2}$ Szent István University Ka- \\ posvár Campus, H-7400 Kaposvár, Guba S. str. 40.
}

After the change of regime, Hungary's economy changed fundamentally. In adapting to the new system, many hitherto unexperienced sectors have gained ground and occupied a worthy position in some segment of the economy. Along with the strengthening of the economy, some farmers have developed rural tourism by taking advantage of the tourist attraction of agriculture and creating a new sector. With our thesis we would like to prove, that the new, but already existing types of Short Supply System based on catering enterprises in Zala county are sustainable and has a significant place on the field. To demonstrate this, we made interviews with entrepreneurs and their suppliers. We examined what special difficulties do they have to vanquish to make their enterprises sustainable and operable. First and last, it seems that a new autonomous market segment is forming, that combines old traditions and new trends.

Keywords: management, agriculture, tourism, catering trade, local product

\section{BEVEZETÉS}

A vidéki térségek, a falvak, tanyák és kisvárosok hagyományosan a mezőgazdasági termelés és élelmiszer-alapanyag, illetve élelmiszer előállítás helyszínei voltak Magyarországon (Kalmárné és Zuzana, 2009). Habár az agrár- és élelmiszer ágazat továbbra is meghatározó jelentőséggel bírnak, a termelés keretei megváltoztak: az „ipari" mezőgazdálkodást folytató nagyüzemek és a specializálódott, illetve multifunkcionális feladatokat ellátó kis családi vállalkozások közötti polarizáció felerősödött. A nagyüzemek döntően mennyiségi fejlesztésre alapozott stratégiája mellett egyik kitörési pontként jelenik meg az egyedi, különleges termékek előállítása (Panyor, 2005).

A rendszerváltást követően Magyarország ipari és mezőgazdasági termelése jelentősen visszaesett. Az elmúlt egy évtized folyamán a mutatók lassan emelkedni kezdtek a mezőgazdaság területén, elsősorban a kutatásnak, fej-

*CORRESPONDING AUTHOR 
lesztésnek, a példaértékű nyugati mintáknak és az uniós támogatásoknak köszönhetően. Jelentős szerepet töltöttek be ebben a fellendülésben azok a gazdálkodók, akik, termékeiket turisztikai vonzerővé tudták formálni. A termelők között egyre többen ismerték fel a gasztronómia és a turizmus jelentőségét. Gondoljunk például a glokalizációra, amelynek lényege a globális áruk helyi környezethez való igazodás utáni újra lokálissá válása. Ilyen például napjainkban a hamburger, amely világszerte elterjedt és elérhetővé vált minden kontinensen, garantálva mindig ugyanazt az ismert ízvilágot. A termelők azonban egy idő után elkezdtek kísérletezni és különböző változatokat készítettek, amely széleskörü termékpalettát eredményezett a fent említett kategórián belül. Az egyre bővülő kínálati struktúrák alátámasztják, hogy igény van ezekre az újításokra. Az újonnan létrejövő lokális értékekre építő éttermek, gasztro bárok és egyéb vendéglátó egységek vonzzák a turistákat, akik azért indulnak útnak, hogy kipróbálják a világban ismert ételek egyénileg újra gondolt, átformált verzióit, valamint helyi jellegzetességek hagyományok szerinti változatait, amelyek minden vidéken más és más ízvilágot képviselnek. Az urbanizálódott ember annyira elszokott az agrárkörnyezettől, hogy a termékek előállításán túl az állatok látványa is élményekkel tölti el, így számos gazda megnyitotta kapuit a látogatók előtt. A legtöbb látványgazdaságban az állatok, a különféle kézműves élelmiszerek előállításának kipróbálása, a termékek vásárlási lehetősége adja a hozzáad ott értéket, de van, ahol ezek mellett falusias környezetben biztosítanak szállást a feltöltődni vágyó turistáknak.

A fentebb leírtakat figyelembe véve pilot kutatásunk céljaként tűztük ki, hogy három vezetői és három beszállítói interjú segítségével bemutatjuk a vizsgált gazdaságok napi működésére ható közvetett és közvetlen problémákat valamint a mezőgazdaság és a turizmus kapcsolatából adódó lehetőségeket, mintegy perspektívát adva a téma iránt érdeklődő olvasók számára.

\section{A falusi turizmus jellegzetességei hazánkban}

Magyarországon a falusi turizmus a falusi fizetővendéglátás kialakulásával kezdődött, amelynek magyarországi kiépítésében nagy szerepe volt az 1929ben megalakuló Országos Magyar Weekend Egyesületnek, majd 1936-tól az Országos Magyar Vendégforgalmi Szövetségnek (Rehák, 2011). Az olcsó szállásoknak köszönhetően az 1930-as évek végére az alsó-és középosztályok számára is népszerűvé vált a vidéken történő nyaralás. Különösen a Balaton, a Bakony és a Mátra-Bükk környéke kínált jó színvonalú szállás-és vendéglátóhelyeket. Ebben az időszakban a belföldi vendégforgalom 30-35\%-át a falusi szálláshelyek elégítették ki. (Molnár és Remenyik, 2017). A II. világháború vége és a velejáró gazdasági összeomlás csaknem teljes mértékben megszüntette a 
vidéki vendéglátást és az arra irányuló igényeket is. Az ötvenes években kialakuló szocialista gazdaságpolitika hatására, a teljes hazai turizmus tekintetében jelentős visszaesést mutatott. Az 1960-as évektől a szálloda beruházások magas költségei miatt a szakhatóságok mindinkább a (magántőkés) fizetővendéglátás bővülését szorgalmazták. 1964-65-re több tízezer férőhelyes kempinghálózat épült ki, ekkor több mint egymillió szocialista országból érkező turista látogatott Magyarországra (Raffai, 2014).

A szakszervezeti és vállalati üdülőhálózatok megjelenésével eleinte háttérbe szorult, majd csaknem teljesen meg is szűnt a kikapcsolódásnak szóban forgó formája. Ebben az időben csak a legfrekventáltabb helyeken tudtak a szálláshelyek és turista kínálatok fennmaradni.

A 80-as évek közepén indított idegenforgalmi koncepcióban már szerepelt a falusi turizmus, így a 90-es évektől már az ágazat újjáéledéséről beszélhetünk (Kovács, 2003), melynek mozgatórugói a városi értelmiségiek voltak, akik vidéki parasztházakban kerestek vagy alakítottak ki maguknak szálláshelyeket. A 80-es évek végén a Magyar Agrártudományi Egyesület volt a civil összefogás kezdeményezője. Az újraéledésben a 30-as évek hazai tapasztalatai, továbbá a 80-as években, Ausztriában és Németországban látott jó példák játszottak közre. A 30-as és 90-es évek a vidék számára egy gazdaságilag nehéz, válságos időszakot jelentett, melyből a vidéki családok egy része a turizmus révén próbált kilábalni (Kovács, 2016). A 90-es években a gazdálkodók szerepe a falusi turizmusban - a 30-as évek hazai gyakorlatához, valamint az osztrák, német stb. példákhoz képest - még marginális volt. A családi gazdaságok kialakítása ekkor indult a privatizáció és kárpótlás révén. Aki családi gazdaság kialakítására törekedett, inkább föld- és eszközszerzésen, semmint több lábon álláson és turizmuson gondolkodott. A főszereplő az a vidéki középosztály - elsősorban a falusi, vidéki asszonyok -, akik helyben szerveződve elindították a falusi vendéglátást. (Kovács, 1993; Csordás, 1998; Kulcsár és Lakner, 1996). A cél az volt, hogy az addig kihasználatlanul álló szálláshelyeken történő vendégfogadásokkal plusz jövedelmekhez segítsék a családokat, valamint a mezőgazdasági termékek közvetlenül juthassanak el a piacra. Ezen folyamatokat segítették a megyei idegenforgalmi irodák, amelyek bekapcsolták a fizető vendéglátásba a falvakban található szállásadást kínáló házakat. 1994-ben megalakul a Falusi Turizmus Országos Szövetsége Magyarországon (FATOSZ), mely szervezet célul tűzte ki a vidéki és agrártérségek gazdasági, társadalmi és kulturális fejlesztését, illetve a falusi turizmus minőségének folyamatos bővítését. Eredményei közé tartozik egyebek mellett a falusi szálláshelyek osztályba sorolási rendszerének és minősítő feltételeinek kidolgozása, valamint szaktanácsadói 
hálózatnak a kialakítása (Molnár, 2017). Az agroturizmus feltüntetése a szervezet nevében jelezte, hogy az jelentős részét képezi a falusi turizmusnak. A 2004-es Európai uniós csatlakozás pedig elhozta a szükséges politikai támogatást. A Közös Agrárpolitika reformjának központi tényezőjévé a vidékfejlesztés vált. Egy egyedülálló finanszírozási és programozási eszközt alkottak az 1290/2005/EK rendelettel, az Európai Mezőgazdasági Vidékfejlesztési Alapot. Ezzel igyekeztek a mezőgazdasági és az erdészeti ágazat versenyképességét javítani, továbbá a környezet és a vidék állapotát javítani és az életminőség színvonalának emelése mellett ösztönözni a gazdákat tevékenységük diverzifikálására. Magyarországon 2007 és 2013 között az Új Magyarország Vidékfejlesztési Stratégiai Terv lépett életbe, amely az unió által támogatott programra reflektált. Ehhez kapcsolódott a FATOSZ Falusi és agroturizmus stratégiája, amely a 2011 és 2020 közötti 9 évre határoz meg irányelveket. Három fejlesztési súlypontot jelöltek meg programjukban: a jogi és pénzügyi háttér biztosítását, a szervezettséget és együttműködést, végezetül a marketing tevékenységet. A legfontosabb azonban mégis a következő: „A falusi és agroturizmus olyan komplex tevékenységgé fejlesztendő, ami a települési és kistérségi szinten egymásba kapcsolódó turisztikai szolgáltatások rendszerét alakítja ki, és ezzel a fenntartható vidéki turizmusfejlesztést ösztönzi (Csizmadia, 2016). Annak ellenére, hogy 1990-es évek elejének spontán módon szerveződő falusi turizmus valójában a munkahely elvesztéséből származó kiútkeresés egyik következményének tekinthető, sokan hitték, hogy a falusi turizmus lesz majd képes a vidéki gazdaság válságának feloldására. Ez azonban nem következett be és húsz évvel később, a 2010-es KSH mezőgazdasági összeírás adatai szerint az 567446 egyéni gazdaság mindössze 7\%-a foglalkozott egyéb gazdasági tevékenységgel, köztük vendégfogadást vagy mindössze az összes gazdaság 0,2\%-a végzett. A falusi vendégfogadók száma 2009 óta folyamatosan csökken annak ellenére, hogy az utóbbi években több milliárd forint fejlesztési forrás jutott vidéki turizmus címszó alatt falusi vendéglátásra is (Molnár, 2017).

Mindezekkel egyetemben a turisták részéről a speciális területek felé való érdeklődés (védett területek, egyedi természeti jelenségek, tájjellegű nevezetességek, rendezvények) egyre nagyobb mértékben megfigyelhető. A falusi turizmus piacán is megindultak a vendégkör igényeit mind teljesebben kielégítő specializált termékek fejlesztési munkálatai. A speciális kínálatokkal szembeni követelmények, a marketing-stratégia szellemében a konkrét vendégkívánságokhoz és - igényekhez igazodnak. Ahhoz, hogy egy szakosodott területen a falusi (vidéki) gazdák, illetve vendégfogadók versenyképesek legyenek és ma- 
radjanak, - az általános minőségi követelményeken túlmenően, speciális kritériumokra is fel kell készülniük, amit rendszeresen az új igényekhez, időrőlidőre hozzá kell igazítaniuk (Szabó, 2012).

Zala megyében csak úgy, mint az ország jelentős részén a turizmus csak szezonálisan tudja az igényeket kielégíteni, ezek mögött azonban egyre többször és erőteljesebben jelenik meg a mezőgazdaságnak az az áru előállító szerepe, amely direkt módon a termelőtől vásárolja meg a feldolgozandó, értékesítendő termékeket. Ezáltal egy magasabb minőség megteremtésére van lehetőség, amely képes felvenni a versenyt a bolti alapanyagokból előállított élelmiszerekkel szemben. Emellett másik nagy előnye az ilyen fajta együttműködésnek, hogy a kis termelők érdekeltté válnak a zöldség-, gyümölcs-, hús- és egyéb élelmiszeripari növények termesztésében, előállításában, ezáltal egy bizonyos mértékig képesek felvenni a versenyt a nagyobb áruházláncokkal szemben.

Interjúink során bebizonyosodott, hogy a falvakban a jó példa, erős motiváló tényezőként hathat azokra a lakosokra, akik családi házuk kertjét eddig elhanyagolták, lehetséges kapacitásait nem használták ki egészen. Ezeknek az embereknek jól képzett, felkészült mentorokra van szükségük (Gelencsér és mtsai, 2020), akik újra megtanítják őket a gazdálkodás szépségeire és arra, hogyan és hol értékesíthetik az általuk fel nem használt terményhányadot.

\section{ANYAG ÉS MÓDSZER}

Dolgozatunkkal bizonyítani kívánjuk, hogy a Zala megyéből hozott példák, újfajta szemléletmódú együttműködésen alapuló vállalkozások, - mind turisztikai, mind mezőgazdasági szempontból - életképesek és helyük van a piacon. Kiválasztott interjúalanyok segítségével bemutatjuk a piac rájuk eső szegmensének nehézségeit és lehetőségeit, melyeket a megkérdezettek válaszai, és saját következtetéseink alapján állítottunk össze.

A téma frissessége miatt kevés szekunder információ állt rendelkezésünkre, ezért primer kutatásra helyeztük a hangsúlyt. A céljaink elérése érdekében összeállítottunk két mélyinterjú kérdéssort. Az egyik segítségével a termelők, míg a másik kérdéssor felhasználásával a vendéglátóegységek jelenlegi és jövőben lehetőségeit és kiugrási alternatíváit vizsgáltuk. Az interjúk elkészítésének ideje 2018. tavaszától nyár végig húzódott, mert a nyári szezon miatt a vendéglátásban dolgozók megkérdezésére nem volt lehetőség, a beszállítóik elérhetőségét pedig csak rajtuk keresztül tudtuk feltérképezni. Az interjúalanyok kiválasztása során az volt a szempont, hogy a megkérdezett rendelkezzen valamilyen rá jellemző helyi sajátossággal, kellő szakmai tapasztalattal, továbbá sikeresen megvalósított kölcsönös együttműködést a mezőgazdaság és 
a turizmus területén. E szempontoknak az alábbi vállalkozások feleltek meg, melyeket az 1. táblázatban és a 2. táblázatban foglaltuk össze.

\section{1. táblázat}

A vendéglátó egységek vezetőinek álláspontja

\begin{tabular}{|c|c|c|c|}
\hline & $\begin{array}{l}\text { I. interjúalany } \\
\text { (interviewee I.) }\end{array}$ & $\begin{array}{l}\text { II. interjúalany } \\
\text { (inetrviewee II.) }\end{array}$ & $\begin{array}{l}\text { IV. interjúalany } \\
\text { (interviewee IV.) }\end{array}$ \\
\hline Neme (sex) & férfi & nő & férfi \\
\hline $\begin{array}{l}\text { Székhely } \\
\text { (seat) }\end{array}$ & Zalaegerszeg & Bázakerettye & Keszthely \\
\hline $\begin{array}{l}\text { Indulás, év } \\
\text { (start, year) }\end{array}$ & 2013 & 2009 & 2013 \\
\hline $\begin{array}{l}\text { Filozófia } \\
\text { (philosophy) }\end{array}$ & $\begin{array}{l}\text { (1) Nem mindegy, hogy milyen } \\
\text { a hely és az sem, hogy hol van } \\
\text { (2), a belső designnak is rend- } \\
\text { ben kell lennie (3). Roppant } \\
\text { fontos, hogy mit adunk a ven- } \\
\text { dégeknek (4), és nem utolsó } \\
\text { sorban az sem mindegy, hogy } \\
\text { ezt hogyan tesszük meg, ho- } \\
\text { gyan szolgáljuk ki őket (5). }\end{array}$ & $\begin{array}{l}\text { "Azt mondják rólunk, } \\
\text { hogy itt minden olyan } \\
\text { igazi. Pedig mi nem } \\
\text { vagyunk mások csak } \\
\text { megmaradtunk olyan- } \\
\text { nak, amilyenek vol- } \\
\text { tunk." }\end{array}$ & $\begin{array}{l}\text { „Olyan közösségi él- } \\
\text { ményt akarunk, } \\
\text { amelyben nem mi } \\
\text { vagyunk a főszerep- } \\
\text { lők, hanem az asz- } \\
\text { taltársaság.” }\end{array}$ \\
\hline Profil (profile) & $\begin{array}{l}\text { gasztrobár, hamburgerező, } \\
\text { street food }\end{array}$ & hotel és étterem & bisztró \\
\hline
\end{tabular}

Table 1 The position of the managers of the catering units

2. táblázat

A beszállító interjúalanyok jellemzése

\begin{tabular}{lccc}
\hline & $\begin{array}{c}\text { III. interjúalany } \\
\text { (interviewee III.) }\end{array}$ & $\begin{array}{c}\text { V. interjúalany } \\
\text { (interviewee V.) }\end{array}$ & $\begin{array}{c}\text { VI. interjúalany } \\
\text { (interviewee VI.) }\end{array}$ \\
\hline Neme (sex) & nő & nő & nő (vegetáriánus) \\
Székhely (seat) & Baracska & Rezi & Cserszegtomaj \\
$\begin{array}{l}\text { Indulás, év } \\
\text { (start, year) }\end{array}$ & 2013 & 2010 & 2013 \\
Profil (profile) & sajtelőállítás & $\begin{array}{c}\text { állattartás, növény- } \\
\text { termesztés }\end{array}$ & biokertészet \\
\hline
\end{tabular}

Table 2 Characterization of supplier interviewees

Az interjú kérdésére adott válaszokat diktafon segítségével rögzítettük, amelyre előzetesen a válaszadóktól engedélyt kértünk. Az anonimitás érdekében a válaszokat I.-VI. interjúalany megjelöléssel kódoltuk. A kutatás megkez- 
dése előtt személyes ismeretségi körünkben teszteltük a kérdéseket annak érdekében, hogy a kapott válaszok a kutatás céljaival összhangban legyenek, esetleg a kevésbé érthető kérdéseket ki tudjuk szűrni. A megkérdezések alatt nem történt semmilyen rendkívüli esemény, amely a kapott eredményeket befolyásolhatta volna.

Kutatásunk nem reprezentatív, de eredményei alapján ok-okozati összefüggések megfogalmazhatók.

\section{EREDMÉNYEK}

Első lépésben a vendéglátókkal készült interjúkat vetettük össze egymással, hogy átfogó képet kaphassunk arról, hogyan, és miként képesek a vállalkozásaik működni, illetve mit tettek és tesznek azért, hogy a vállalkozásuk sikeres és egyedülálló legyen a térségben működő hasonló profilú vállalkozásokkal szemben.

\section{A vendéglátó egységek vezetőivel készült interjúk}

A már említett személyek megismerése után először arra voltunk kíváncsiak, mit gondolnak a megkérdezettek a mezőgazdaság és a turizmus kapcsolódási pontjairól. I. interjúalany úgy vélekedett, hogy a fine dining étkeztetés már nem rentábilis és túl magas ár kategóriát képvisel, valamint a túl sok külföldi dömpingáru, főleg zöldségek terén kiszorítja a drágább, minőségi magyar termékeket a piacról. Ezért a termelőket ösztönözni kell arra, hogy a kiskerti kultúrákat maguk állítsák elő és próbálják eladni akár a piacon, akár más lehetséges helyeken. II. interjúalany ezt azzal egészítette ki, hogy számukra nagyon fontos, hogy az étel minőségét az alapanyag frissessége határozza meg, ezért ők támogatják a helyi termelőktől való vásárlást. A IV. interjúalany San Sebastiant hozta fel példaként, ahol a baszkok saját gasztronómiai identitást hoztak létre azáltal, hogy az alapanyagoktól kezdve a konyhatechnológián át minden helyi, és minden száz százalékosan baszk. Szerinte a legfontosabb a régió mezőgazdaságára épülő vendéglátás, amelyet turisztikailag kell értékesíteni. A két ágazat jövőbeni kapcsolatáról, lehetőségeiről az üzletasszony egy kicsit keserűen jegyezte meg, hogy jelenleg a sajt az egyetlen stabil beszállított termékük, a többi terméket, főleg a húst nem tudják a beszállítók egyenletesen produkálni, míg a franciák ezt már régen megoldották. Az I. interjúalany problémaként említette, hogy a Balatonon megszűnt a halászat, így az ottani vendéglátóegységekben nem lehet balatoni halat kapni, csak fagyasztott argentin hekket, vagy a keltető tavi tenyésztett halakból válogathat a szakács. A IV. válaszadó szerint a helyi vendéglátásnak és mezőgazdaságnak nem csak turisztikai aspektusa 
van, hanem makrogazdasági is. Ezért nagyon fontos, hogy ha egyszer valóban vidéki életpálya modellről szeretnénk beszélni, ott úgy kell a mezőgazdaságnak megjelennie, mint egy alapvetően a helyiek által megbecsült alternatíva, hiszen a helyi emberek veszik és eszik ezeket a termékeket. Fontosnak tartotta kiemelni, hogy ha éves szinten akar valaki éttermet üzemeltetni, amelynek alapját a helyi termék kínálat teszi ki, azzal jelentős mértékben hozzájárul új munkahelyek létrejöttéhez. Ez azonban így önmagában kevés. Szükség lenne még a Georgikonban egy zöldség-, hús- és tejfeldolgozó üzem létrejöttére, amelyek termékeinek csomagolása is helyben történne. Ezáltal létrejöhetne egy helyi brand, amellyel be lehetne lépni a piacra. További előny lehetne, hogy a 25-30 km-es körzetben levő gazdáknak is lehetőséget biztosítanának arra, hogy fair trade szemlélet alapján beszállíthassák terményeiket, jószágaikat, így ez nem csak a Georgikon, hanem az egész vidék lakosságának érdekeit szolgálná. Az I. interjúalany szerint a legfontosabb kormányzati lépés a két ágazat tovább fejlődésének és együttműködésének érdekében a túlszabályozások feloldása, például az étkeztetési rendszerben. A jelenlegi népegészségügyi szabályok értelmében, népkonyhákra, menzákra nem lehet a kistermelők által termelt alapanyagokat élelmezési céllal felhasználni. Emellett egy másik megoldatlan probléma, mellyel hazánknak szembe kell néznie az elkövetkező évek folyamán, az alacsony bérekből, képzetlen munkaerőből (Kőmüves és mtsai, 2016) magas adókból származó gazdasági anomáliák és az ezekből eredő következmények megoldása. Jelenleg az éttermek magas árai többek között a dolgozók utáni különböző költségeknek, magas adóknak és nem az alapanyagok árának köszönhetők. Az osztrákoknál például a legnagyobb költségtényezők a bérek és járulékok, így nem meglepő, ha a hazai konyhai személyzet is inkább a határon túli lehetőségeket keresi.

A következő kérdéssel azt vizsgáltuk, hogy az egyes vendéglátóegységek mekkora beszállító hálózattal rendelkeznek. Az I. interjúalanyunk három helyről szállíttat húst, melyek közül a sertés és a marha az egyedüli, amely állattartó telepről érkezik. A bort és a sört ismert helyi vállalkozók biztosítják. Zöldséget egyelőre nem tudnak a környező településekről beszerezni. A beszállítók kiválasztása során a megtermelt termékek minősége döntő. A IV. interjúalany kiterjedt beszállítói hálóról beszélt. A legfontosabb kritériumok velük szemben, a korrekt évekre előre tartható ár meghatározása, valamint a pontos szállítási időintervallum megadása. A II. interjúalany esetében a nagykanizsai termelői piac jelenti az alapanyag központot. Számukra a szállítási idő pontos betartása, a termékek állandó rendelkezésre állása és a kiszállítás megléte a fontos. A termékek minőségével kapcsolatban az általános vélemény az volt, hogy a magyar áruk minősége közel azonos vagy jobb mint a külföldi kínálat. A II. 
megkérdezett a kérdéssel kapcsolatban példaként említette, hogy korábban volt külföldi beszállítója, akivel szerződést kellett bontania a nem megfelelő minőségi kritériumok miatt.

A piac kínálatáról megoszlottak a vélemények. I. interjúalany szerint a megjelenés a legfontosabb a vevő számára, mert uniformizálódott szokások vannak, miközben a különleges ízekre helyeződik a hangsúly és a kinézet háttérbe szorul. Fontos szerep jut a folyamatos K+F-nek, mely elősegíti a termék kínálat frissítését. II. válaszadó a magas minőségű alapanyagokat említi, kiemeli a természetkövető, rendszeresen változó étlapot, napi menü ajánlatot, amely a piacról hozott termékekből készül. Valamennyi interjúalany a rendezvényeken való megjelenés fontosságát hangsúlyozta. IV. interjúalany kiegészíti ezt a Balaton szerepének erősítésével „ahol a jó étteremtől a csárdán és bisztrón át, a part menti büféig minden megtalálható és minden a Balatonról szól". Fontosnak tartja a Balaton parti rendezvényeket, bulikat és a koncerteket. Példaként említette a D-napot, Gasztro Pikniket, amely hagyományteremtő szándékkal indult el. A IV. válaszadó is hangsúlyozta a rendezvények szerepét, azzal kiegészítve, hogy a jövedelmezőségük fenntartása érdekében célravezető lehet, akár a helyszín biztosítása is, így a természeti, illetve speciális gasztronómiai vonzerő generálhatja a forgalmat. Esetükben a siker kulcsa az, hogy gondolkodásmódban, üzletpolitikában évekkel a környékbeli éttermek előtt járnak, ezáltal sikeres a vállalkozás. A I. interjúalany szerint az lenne az igazi siker, ha a meglévő pályázati forrásból - amely a balatoni régióra irányul - helyben is maradna a KKV szektor számára. Arra a kérdésre, hogy esetleg a későbbiekben terveznek-e szorosabb együttműködést a vállalkozásuk és a mezőgazdaság között, mindannyian pozitív választ adtak. A II. válaszadó a kérdéssel kapcsolatban elmondta, a füszernövények után, a zöldségeket is maguk szeretnék termelni, tehát egy saját konyhakert létrehozását fontolgatják, hogy minél kisebb mértékben függjenek a beszállítóktól. A soron következő kérdésre, mely a glokalizációra vonatkozott, mindenki egy-egy általa megálmodott különleges, helyi termékeken alapuló étellel válaszolt. A I. interjúalany specialitása volt a Laza Szendvics, (a Laza itt a Zala szó betűivel történő játék eredménye) amely vaddisznó lapockából készült húspogácsát, zelleres-majonézes almasalátát, szilvás hagymasalátát, és egy kevés tökmagolajat tartalmazott. A II. válaszadó speciális kínálata a Muraföldi Burger, amelynek alapja dödölle tészta, a hús helyi mangalicából készült, és minderre helyben savanyított kerekrépa salátát tesznek. A IV. válaszadó egy egész sor glokális terméket sorakoztatott fel. Megtalálható náluk a teljesség igénye nélkül például a vízi kutya, amely a hot-dog lokalizált megfelelője. Mindhármukat motiválja a jelenség, hiszen a nehéz ételek és a pörköltek ideje leáldozóban van, tudtuk meg a II. válaszadótól. Míg a II. 
válaszadó a további glokális ételekben látja a márkanév erősítésének lehetőségét, addig IV. szerint nem csak a vállalkozásra van befolyással a jelenség, hanem az emberek gondolkodásmódjára, tartására, életmódjára, az egész életre.

Pénzügyi stabilitásukról, megtudtuk, hogy minden vállalkozás önerőből működik, pályázati források nélkül. A II. válaszadó egyedüliként indult pályázati forrásokért, de ez idáig még egyetlen egyszer sem sikerült támogatást elnyerniük.

\section{Beszállítókkal végzett interjúkból az alábbiak emelhetők ki:}

Ezt követően térjünk át a beszállítókkal készült interjúkra, abból a célból, hogy megismerjük helyzetüket, adottságaikat és azt, hogy mennyire képesek sikeresek, és úttörők lenni a mezőgazdasági termelésben.

Az első kérdésünk arra irányult, hogy milyen egyéb, kiegészítő tevékenységek szükségesek ahhoz, hogy mezőgazdasági tevékenységüket fenn tudják tartani. Az V. és a VI. megkérdezettek turisztikai kínálatot nyújtanak a mezőgazdasági termelés mellet. Mindkét helyen biztosítanak szállást, az ételek alapanyagait pedig a saját kertészetből fedezik. A III. interjúalany az eladás mellett, saját fogyasztásra is termel, valamint 1200 négyzetméteren zöldség és gyümölcstermesztéssel foglalkozik. Ebből rögtön az is kiderült, hogy míg az első két esetben nem tudnak kizárólag csak az egyik ágazatból megélni, addig a harmadik helyen képesek magukat el-, és fenntartani. Állításuk szerint „keresnek annyit, mintha fóállásban dolgoznának valahol, de meggazdagodni ne fognak belőle". Egyik helyen sem volt még szükség bankhitelek felvételére, korábban sem álltak kapcsolatban bankokkal, így ami a vállalkozásokat ténylegesen működteti, az a befektetett alázatos munka, illetve V. interjúalanynál megjelenik a közmunka program. VI. válaszadó kitért arra, hogy ő hetente maximum egyszer-kétszer hagyja el otthonát, valamint csak a legszükségesebb dolgokat vásárolja üzletekből, így költségeit minimalizálni tudja. Bár mindezeket alapvetően sikernek lehet elkönyvelni, nem lehet elmenni amellett -a már korábban említett tény mellett-, hogy a jogszabályi háttér és a politikai megítélése az ágazatnak, nagyon megnehezíti ezeknek a vállalkozásoknak a helyzetét. Ezt mindhárom helyen megerősítették, elhangzott többek között az is, hogy a hozzáállás alapvetően pozitív. Ennek egyik hozadéka, hogy az őstermelői tevékenység és falusi turizmus adómentes. Ezzel szemben azonban általános érdektelenség tapasztalható, a termelőt nehéz beilleszteni az ellátás folyamatába, mutatott rá VI. interjúalanyunk. A közösségi kerttel addig nem tudnak új felvevő piacokat keresni, ameddig meg nem szerzik a jogosultságot a terjesztésre. A III. válaszadó elmondta, hogy ők nem csak vásárokon, rendezvényeken, termelői piacokon értékesítenek, hanem házhoz is szállítanak. Sőt keresnek új lehetőségeket 
a terjesztésre, mert van még kapacitásuk többet termelni. V. és VI. interjúalanyok az őstermelői jogosultságon keresztül tudnak a felvásárlóknak szállítani, ezen túl a faluban működő vendéglátóegységben megszállóknak is főzhetnek már a terményekből. Emellett folyamatban van a piacra történő szállítás engedélyezése, ennek első lépcsője, hogy a központba, a népkonyhára már bevihették a termékeket, amelyekből így friss, egészséges ételek készülhetnek a lakosok számára. A támogatásra azért lenne szükség, mert munkát ad az embereknek, egészséges ételek kerülhetnek az asztalokra és a föld sem marad kihasználatlanul. A VI. interjúalany elmondta, hogy a jelenlegi konvencionális gazdálkodás a mezőgazdasági területek teljes kihasználásán alapul. A szabályozás puhítását az is indokolja, hogy a piac szabályozni tudja önmagát: aki nem oda illő terméket próbál eladni, az kikerül az árusítási jogosultság alól. Ezzel a gyengítéssel elő lehetne segíteni, hogy a valódi egészség tudatos táplálkozás fontosságára is ráirányítsák a figyelmet. Rámutathatnak arra is, hogy nem kell a boltban megvásárolni azokat a termékeket, amiket a kertben is lehet termeszteni. A közösségi kert esetében további problémát vet fel a jól képzett, felkészült szakmai vezető hiánya, akikre a falubeliek hallgatni tudnának és megfogadhatnák tanácsait. Egyetértünk Kőmüvesés mtsai. (2017), véleményével, aki vezetőképzés szerepét hangsúlyozza. Kezdetben VI. válaszadó volt, aki átadta tudását és segítette a tanulás folyamatát, amit változó lelkesedéssel és érdeklődéssel fogadtak a falubeliek. Az oktatás célja az volt, hogy felkeltse az emberek figyelmét a mezőgazdaságban folytatható vegyszermentes termelés iránt. A további fejlődéshez, amely a vendégforgalom teljes mértékű kiszolgálását célozza, elengedhetetlen lenne egy szakértő folyamatos jelenléte. Szeretnék a főzőkonyhát teljes mértékben kihasználni, amely az önellátás, önfenntartás kiterjesztését jelentené, amelynek nem csak létjogosultsága van, de igény is lenne rá. Egyre többen vannak, akik az étel miatt térnek vissza a faluba. Ők azok, akiknek igényeit igyekeznek maximálisan kielégíteni, de emellett folyik egyfajta igényteremtés is, mégpedig az emberek megismertetése az egészséges, friss, hazai termékek kínálatával, akik reményeik szerint, ha egyszer kipróbálták, mindig keresni fogják ezeket a termékeket. Azonban nem szabad elfelejteni azt sem, hogy a hagyományosnak mondható magyar ételek továbbra is megkerülhetetlenek maradnak. Ezzel kell szembe néznie azoknak a fiatal szakácsoknak, akik külföldi tapasztalatszerzés után hazatérnek és hasonló elveken alapuló, nívós éttermeket kívánnak nyitni. Számukra a kreativitás jelentheti a megoldást a fennmaradásra, ahogy azt a II. és a IV. válaszadók esetében is láthattuk. A fentebb említett kezdeti szoros együttműködés eredménye lett a IV. és a VI. válaszadó kapcsolata is. VI. interjúalany viszont rámutatott az együttmúködés gyengéjére is: tudatosítani kell a megrendelőkben, hogy már 
az év elején, a vetés előtt jelezzék azokat az igényeiket, amelyeket majd az év folyamán a kertnek ki kell elégítenie, mert ez által biztosan nem termel majd felesleget. Ezt egy tanulási folyamatként jellemezte, ahol a megrendelő megismeri a kertek adottságait, lehetőségeit, korlátait; a termelő pedig azt, hogy melyek azok az optimális igények, kritériumok és mennyiségek, amelynek neki meg kell felelnie a sikeres együttműködés fenntartása érdekében. Azt viszont mindenképpen pozitívumnak tartja, hogy amennyiben ő éppen nem tudja a termékeket eljuttatni, akkor akár házhoz, vagy a bevásárló közösségbe is elmennek értük.

A III. válaszadó elmondta, hogy ők nem állnak partneri viszonyban senkivel. Ez arra enged következtetni, hogy a II. vállalkozás bár vásárol az ő termékeikből, de ez csak egy egyirányú kapcsolatként működik. Ettől függetlenül a vevőik nagyon elégedettek a prémium minőségű termékekkel, de az igazsághoz az is hozzá tartozik, hogy sok a selejt termék és a felkészületlen termelő a piacon, így nem igazán akadnak versenytársaik a szférában.

A beszélgetések legizgalmasabb pontjává a glokalizációval kapcsolatos kérdéskör vált, hiszen eddig példátlan módon megosztotta a válaszadókat. A III. válaszadó esetében ez egy teljesen ismeretlen fogalom volt, a vezető nem kívánt ezzel foglalkozni. A további két válaszadó esetében azonban két teljesen eltérő vélemény rajzolódott ki. Az V. interjúalany nagyon pozitívan vélekedett a jelenségről és annak hatásairól. Véleménye szerint ez egy nagyon hasznos és fontos dolog, már csak azért is, mert a nagypiaci termékek helyben készítése fellendítheti a munkaerő piacot és ezzel egy időben turisztikai kínálatot is teremthet. Hozzátette, hogy az emberek elszoktak a zöldség fogyasztásától, a változatosságtól, ezzel egy kicsit vissza lehet terelni őket ebbe az irányba. Emellett az uniformizálódott szokások megtörése is cél lehetne, amelyet akár a hagyományos ételek „új köntösbe bújtatásával” is el lehetne érni. Ezek mentén látható, hogy nem csak befolyásolja a faluban végzett munkájukat, de teljes mértékű motiváló tényezőként is jelen van a globális kínálat lokálissá válása. A VI. interjúalany gondolatai elsőre teljes mértékben szemben helyezkednek a fentebb olvashatókkal. Azzal indította válaszát, hogy nem tartja egészségesnek azokat a termékeket, amelyek e jelenség mentén készülnek el, ezért nem is tartja követendő útiránynak. A globális termékekre reflektálva azt állítja, hogy az „ember szervezete úgy működik, hogy azokból az elemekből, amiket a táplálékból kap, be tudja állítani magát egy adott éghajlatra. Ezzel akkor van gond, ha valaki például túl sok spanyol, olasz gyümölcsöt fogyaszt úgy, hogy nem ezeken a területeken él. Ezeknek a szállítása még szennyező is”. Ezért szükséges, hogy minél szűkebb körből szerezzük be, amit el akarunk fogyasztani - foly- 
tatta. Jól látszik, hogy bár az elején nem akart egyetérteni a jelenség létjogosultságával, a végén saját maga fejtette ki, a helyi termékek vásárlásának szükségességét, ezáltal öntudatlanul rácáfolva az elején megfogalmazott ellenvéleményére. Az irányzat további fejlődési lehetőségeivel kapcsolatban V. interjúalany szerint még nagyon sok a kiaknázatlan terület. Fontos lenne, hogy a különböző rendezvényeiken jelen lehessenek a kistermelők mindazzal, amit képesek elóállítani és erre legyen kereslet is. Itt megjegyezte, hogy nagy szükségük lenne egy olyan szakemberre is, aki a marketingért felel. Felhívta a figyelmet arra is, hogy a jövőt tekintve a gyerekeket kell elsősorban megismertetni a mezőgazdasággal és annak szépségeivel, mert a szülők már nem fogékonyak erre. VI. válaszadó megismételte, hogy a tanulás nagyon fontos mind a termelő, mind pedig a vendéglátósok számára. Véleménye szerint a sikeres együttműködés kulcsa ebben rejlik. Úgy gondoljuk, mindkét álláspontnak van létjogosultsága és egyik sem működhet külön-külön, csak együtt.

\section{KÖVETKEZTETÉSEK}

A mezőgazdaság és a turizmus komoly fordulópont előtt áll, amelyben nagy szerepe van a már bemutatott termelőknek és étterem tulajdonosoknak, valamint az őket követő generációknak, hogy ezt magasabb szintre emeljék és kiterjesszék az ország egészére. Kutatásunk során megállapítottuk, hogy az emberek szemléletének megváltozásához -akár termelői, akár fogyasztói oldalról nézzük-, szükség van az igényteremtésre, melyet a felelősen gondolkozó vendéglátósok képviselnek. Ők lehetnek azok, akik nem hagyják, hogy az általuk készített ételek külföldről érkező alapanyagokból készüljenek. Ki kell állniuk azért, hogy amit „kiengednek kezeik közül”, helyi értéket képviseljenek, magában hordozva a vidék és az adott régió jellegzetességeit, kiegészítve a természet adta utánozhatatlan ízletességgel. Összességében úgy látjuk, hogy a mezőgazdaság és a turizmus közötti együttműködés, mára jóval túlhaladta az egykori alapszolgáltatásokból álló kínálatot és a piac önálló szegmensévé formálódott. Nagy igény van erre, mert a vidéknek szüksége van egy újfajta irányvonalra, mozgató rugóra, amely a régi hagyományokból építkezik, de folyamatosan képes megújulni. Ma még nehéz ezt működtetni, de az interjúkból látszik, hogy az, aki rendelkezik kellő elhivatottsággal és forrásokkal, annak megtérülő befektetés lehet a jövőre nézve.

Az interjúk alapján az alábbi következtetéseket fogalmaztuk meg:

- a gazdálkodók képzése elengedhetetlen, az eredményes és hatékony termelés biztosítása érdekében. 
- Mintagazdaságok létrehozása szükséges, ahol a falusi gazdálkodók technológiai ismereteinek bővítésére alkalom és lehetőség nyílna.

- Fokozottabb termék jelenlét, a helyi értékek és hagyományok színesebb kínálata, megfelelő marketingstratégia alkalmazása a kereslet növekedését eredményezhetné.

- Fontos a mezőgazdaság elismertségének növelése, visszahódítása a lakosság körében, a falusi életmód előnyeinek minél pontosabb bemutatása és megkedveltetése a mai társadalomban, mely segítségével a falvak elnéptelenedésének, hanyatlásának gátat lehetne szabni. E tekintetben az oktatásnak igen komoly szerepet kell biztosítani.

- A gazdálkodók által elmondottak alapján, javasoljuk a népkonyhákat, falusi iskolákat, és egyéb - helyi termékeket felhasználó - ellátó tereket érintő szabályozások korszerűsítését.

- Támogatni kell, hogy a vendéglátásban gondolkozók prioritásban részesítsék a helyi termékeket, a dömping árukkal szemben. Ez megvalósítható megfelelő kormányzati lépések segítségével és megfelelő marketing munkával.

- Lehetőséget kellene teremteni a vendéglátó egységek üzemeltetői és a helyi termékeket előállító gazdálkodók egymást megismerve, a megfelelő munkakapcsolat kialakítására alkalmas rendezvények szervezésére.

A már meglévő, REL alapon működő rendszerek minél hatékonyabb működtetését szorgalmazni kell, mert ez által biztosíthatja a vendéglátó egységek, a termelők, illetve a térségek és régiók előrelépését, fejlődését.

Köszönetnyílvánítás: A cikk „az EFOP-3.6.1-16-2016-00007-es azonosítószámú „Intelligens szakosodási program a Kaposvári Egyetemen” című program támogatásával készült.

\section{IRODALOMJEGYZÉK}

Berke, Sz., Kőműve,s Zs. (2016). Satisfaction, motivation and personality types by sales leaders in SME sector: a pilot study, In: Andrea, Csata; Bíborka, Eszter Bíró; Gergely, Fejér-Király; Ottilia, György; János, Kassay; Benedek, Nagy; Levente-József, Tánczos (szerk.) Challenges in the Carpathian Basin. Integration and modernization opportunities on the edges of Europe: 13th Annual International Conference on Economics and Business, Kolozsvár, Románia: Editura Risoprint, (2016) 1-16.

Csizmadia, L. (1998). FATOSZ Falusi és agroturizmus stratégiája (2011-2020) Link (Letöltve: 2020. március 14.)

Csordás, L. (1998). Falusi Turizmus kézirat: HU95040101 Phare-program 283-329. 
Gelencsér, M., Szigeti, O., Szabó-Szentgróti, G. (2020). A feldolgozóipari munkavállalók munkaerő-megtartása. Vezetéstudomány/Budapest Management Review, 51(9), 67-79. DOI: $\underline{10.14267 / v e z t u d .2020 .09 .06}$

Kalmárné Hollósi, E, Zuzana, V. (2009). Helyi termékek a vidéki térségek társadalmi-gazdasági fejlődésének szolgálatában, Jelenkori Társadalmi és gazdasági folyóiratok, 4(3-4), 44-48.

Kovács, D. (1993). A falusi turizmus mint új vállalkozási forma terjedése a Keleti Mecsek három településén, Hosszúhetényben, Magyaregregyen, Kárászon. A falu, 1993(4).

Kovács, D. (2003). Falusi vendéglátás Magyarországon, Agroinform Kiadó, Budapest 2003

Kovács, D. (2016). Új jelenségek a falusi turizmusban Magyarországon. The central european journal of regional development and tourism Deturope, 8(1), 1821-2506.

Kőmüves, Zs., Lengyel, L., Bendek, D. (2017). Examination of equal opportunities for women in the Labour market, In: Szendrő, Katalin; Horváthné, Kovács Bernadett; Barna, Róbert (szerk.) Proceedings of the 6th International Conference of Economic Sciences.

Kőmüves, Zs., Berke, Sz., Póra, G. (2016). Survey on Female Managers In: Csata, Andrea (szerk.) Challenges in the Carpathian Basin: Integration and modernization opportunities on the edge of Europe (13th Annual International Conference on Economics and Business), Cluj-Napoca, Románia: Editura Risoprint, 252-266.

Kulcsár, L., Lakner, Z. (1996). A falusi turizmus helyzete és fejlesztésének lehetőségei Gazdálkodás, 29(3), 54-61.

Molnár, Cs., Remenyik, B. (2017). A falusi turizmus helyzete és fejlesztési lehetőségei. Studia. Mundi Economica, 4(5) 44-59. DOI: 10.18531/studia.mundi.2017.04.05.44-59

Panyor, Á. (2005). A hazai ökoméz piaci lehetőségei. Gazdálkodás, 49(3), 65-71.

Raffai, Cs. (2014). Falusi szállásadók innovációs képesség érettségének vizsgálata. Pannon Egyetem, Doktori Értekezés, pp. 258.

Rehák, G. (2011). Turizmuspolitika Magyarországon. PhD-disszertáció. Debreceni Egyetem, Debrecen, pp. 247.

Szabó, G. (2012). A hazai falusi turizmus helyzete és jövőképe. In: Hanusz, Á. (szerk.): A turizmus területi dimenziói. Nyíregyházi Főiskola. 